獣 医 麻 酔 第 10 号 87-90 (1979)

Jap. J. Vet. Anesth. No, 10 87-90 (1979)

臨床ノート

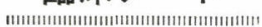

\title{
塩酸ケタミンと GOF の併用麻酔による
}

\section{豚の帝王切開の 1 経験例}

森島隆司 加藤芳隆 竹田三喜夫 渡辺俊交
新迫高志黒松勇蔵 杉田喜與春 菅沼常徳
高橋 貢 北昂

近年, 豚の麻酔については, いろいろな方法が報告さ れているが, 他の動物に比較して, 豚は脂肪組織が多く 麻酔薬の排泄が覀いこと，ストレスに対し感受性が高い こと, 馴致されておらず制御しにくいことなどで, 実際 の麻酔を行う場合, 不都合な点が多い。

とくに帝王切開時の麻酔に関しては, 麻酔薬の胎盤通 過ならびにその通過時間によって胎児に対する麻酔薬の 影響を考虑しなければならない。したがって, 実際の麻酔 に扣いては麻酔薬の選択, 麻酔薬の投与方法执よびその 投与量の決定は，より慎重に行われなけれぱならない。

豚に打㚈る帝王切開時の麻酔方法に関する報告は, 本 好ら $(1974)^{8)}$ の報告によるハロセン，エーテルなどの吸 入麻酔法, William $5^{10)}$, 黑沢ら ${ }^{3)}$ の報告による抱水ク ロラール，ペントバルビタール，硫酸マグネシウムなど の静脈内麻酔法, アザパロン, 塩酸メトミデートなどの 鎮静剂で安静としたのち, 脊髄硬膜外麻酔を併用する方 法 $^{2)}$, 本好 $(1974)^{8)}$ の報告によるアザペロン, 塩酸メト ミデートなどの鎮静剂に局所浸潤麻酔を併用する方法ま たは塩酸ケタミンによる筋肉内麻酔法などが挙げられて いる。

今回, われわれは, 試験的に主たる麻酔を塩酸ケタミ ンで実施し，乞れに補助麻醉として間歇的に GOF 麻醉 を併用した麻酔を行って, 豚の帝王切開を実施してみ た。その結果, 比較的良好な麻酔経過ならびに手術経過 が得られたので，その概要を述べてみたい。

\section{供 試 豚}

学生実習の目的で妊娠末期の豚を養豚業者より購入し た。豚の種類は大ヨークシャー種とハンプシャ一種の交 雑種で, 推定年齢 $2 \sim 3$ 歳, 推定体重 $200 \mathrm{~kg}$ 前後であ り, 経産歷は 4 回の妊娠豚で, 入舎時に分婏予定日より

麻布獣医科大学 干229 相模原市㴊野辺 1-17-71
1 日経過したものであった。臨床所見は, 体温 $37.0^{\circ} \mathrm{C}$, 心拍数 $99 / \mathrm{min} .$, 呼吸数 $23 / \mathrm{min}$., その他の臨床検査に おいても異常な所見は観察されず，麻酔ならびに手術を 実施するには極めて良好な状態であった。また，陰部は 弛緩, 腫脹して拉り, それぞれの乳房も充血腫脹し, 妊 娠末期の正常な所見を示していた。

\section{麻酔方法ならびに麻酔経過}

麻酔にさきだち, Premedication として硫酸アトロピ ン $0.03 \mathrm{mg} / \mathrm{kg}$ を雉部笳肉内に投与し, 投与後約 10 分 を経過した頃に，母豚をゲージ内より誘導して移動保定 器に立位で保定した。保定の際に多少の興奮が観察され たが，とくに騒擾はなかった。Premedicationを行って から約30分を経過した時点で, 塩酸ヶタミン $20 \mathrm{mg} / \mathrm{kg}$ を臂部筋肉内に投与したところ, 投与後約 1 分を経過し た時点より，後躯を沈下しはじめ (Fig. 1), 呼吸の様相 も深くなりはじるた。2 分を経過した頃には, 痛覚なら びに眼瞼反射，咽喉頭反射ならびに筋の緊張は残ってい たが，十分な鎮静効果が得られたので，移動保定器を回

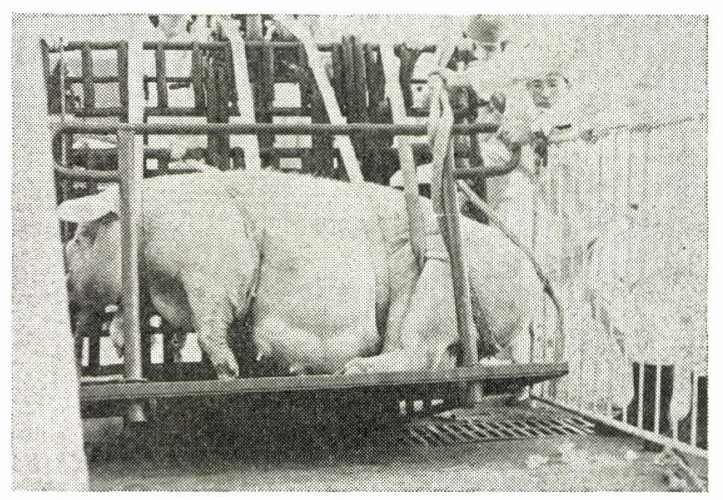

Fig. 1 Onset of anesthesia 1 minute after injection of Ketamine 
転させた後，左側横臥位に保定を行った。

塩酸ケタミン投与後15分を経過した時点では，痛覚な らびに筋の緊張が中等度に減退した状態が钼察されたの で，左側膁部を術野とし，術野の剪毛，剃毛および消毒 を行ったのち，約 $30 \mathrm{~cm}$ にわたる皮膚切開を行って帝王 切開を開始した。

皮膚，皮下織ならびに外腹斜筋，内腹斜筋の順に切開 したが, 切開時には軽度の疼痛と筋の攣縮が観察された ので, $2 \%$ 塩酸プロカインの局所浸潤麻酔を併用した。

腹膜の切開を終了したのち，ただらに妊娠子宮を露出 し, 左側子宮角の子宮体部に近い位置で子宮を切開し た。この間，母豚は四肢の軽度な運動ならびに肢端反射 が観察されたが，腹膜の切開直後は消退した。

子宮体ならびに子宮角は，健康な妊娠子宮の所見を呈 しており，買常所見は観察されなかった。子宮切開を行 ったのち約 20 分の間に, 左側子宮角より 9 頭, 右側子宮 角より 5 頭, 死胎罗 1 頭を含む合計 14 頭の胎况を摘出し た。

摘出した胎児はたた゚ちに臍帯の切断, 胎児の口腔な らびに鼻腔内の羊水を除去し，体表を清拭するなどの処 置を行って，保育箱に收容し保温した。また，母豚の露 出乙心子宮を生理食塩液で洗浄し, 抗生物質を腹膑内に 投与したのち，子宮の切開部位を縫合した。

胎児摘出後 5 分を経過した頃より，母㕄は頭部および 四肢の運動を開始し, 賞醒徴候が観察されはじめたの で, 補助麻酔としてマスク吸入法による GOF 麻酔を開 始した (Fig. 3)。この場合, 麻酔にさきだらマスク法に より酸素 $10 \mathrm{l} / \mathrm{min}$. を約 2 分間吸入させて母豚の脱窒素 をはかり，ついで酸素流量を $4 l / \mathrm{min}$ 、 に減量し， $6 l /$ min.の笑気を混入して Total flow を $10 \mathrm{l} / \mathrm{min}$. とし た。笑気の吸入を開始してから5 分を経過した時点で， ハロセンの吸入濃度を $0.5 \%$ として GOF 麻酔とした (Fig. 2)。

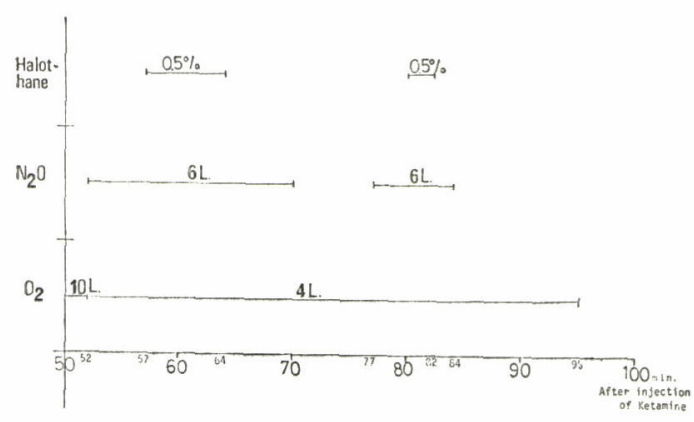

Fig. 2 Process og Inhalation Anesthesla

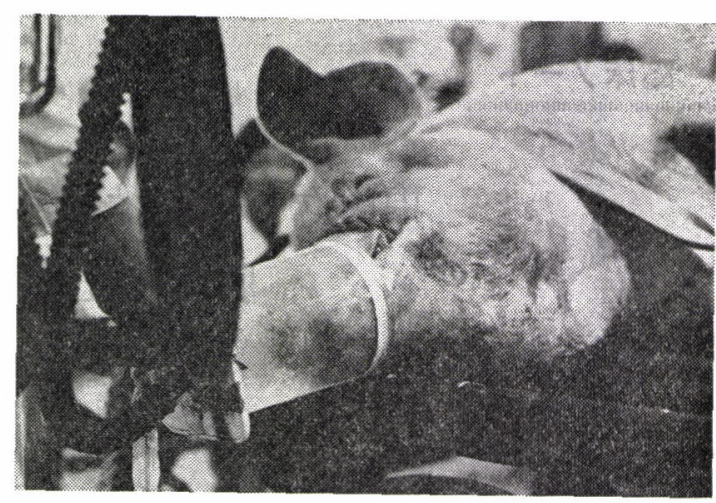

Fig. 3 Inhalation anesthesia (GOF) 62 minutes after injection of Ketamine.

GOF 麻酔に和ける麻酔深度の判定は, 眼瞼反射の状 態と瞬膜の突出した状態, あるいは眼球下垂の状態を観 察して判定し，第 3 期第 1 相の麻酔深度と思われる状態 で維持した。この間に子宮壁と腹膜の縫合を終了した。 八ロセン吸入開始後 7 分を経過した頃より麻酔深度が深 まり始めたので，腹横笳の縫合を行っている途中にハ口 センの吸入を中止して, 酸素と笑気の混合吸入のみとし たが，その後も麻酔深度が浅くならなかったため，、口 センの吸入を中止してから 6 分を経過した時点で, 笑気 の吸入を 7 分間中断した。この間に, 内腹斜筋および外 腹斜筋の縫合を終了し, 皮下組織の縫合を開始した。し かし, 皮下組織の縫合途中, 頭部掞よび四肢の運動が出 現し始めて急激に覚醒し, 皮膚縫合が困難な状態となっ たので, 再び GOF 麻酔を 2 分間継続し, 麻酔深度の安 定を待って, 皮下組織および皮膚の縫合を行った。この 場合, 皮膚縫合を開始する 3 分前にハロセンの吸入を中 止し，その 2 分後には笑気の吸入を中止した。そ乙て酸 素 $4 l / \mathrm{min}$. を吸入させ, 笑気汸るる diffusion anoxia を妨止して手術を終了した。

母豚は皮膚縫合が終了した直後から, 頭部および四肢 の運動が久られ, 覚醒徵候が観察され, 術野の消毒, 抗 生物質の投与などの処置を終了したのち, 保定を解除し 移動保定器からゲージ内へ移動させた。

移動後10数分後には, 覚醒し, 起立動作を頻回に試み るよらになり，術後65分経過した時点で起立した。

\section{心拍数, 体温, 呼吸数の变化}

術前, 術中, 術後に拈ける心拍数, 体温, ならぴに呼 吸数の変化は, Fig. 4 に示したとおりである。

心拍数は，硫酸アトロピン投与前において 99/min., 塩酸ケタミン投与後には $72 / \mathrm{min}$.で減少を示したが， 


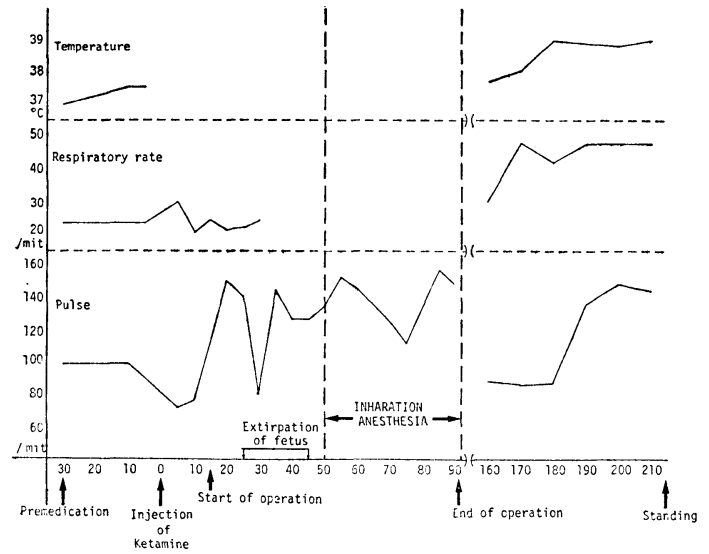

Fig. 4 Exchange of Temperature, Pulse and Respiratory rate

手術開始 5 分前より上昇しはじめ, 手術開始 5 分後には 150/min. に達した。手術開始 7 分後より一過性に下降 しはじめ $77 / \mathrm{min}$. に減少したが, その後は手術終了時 まで 112 156/min. の範囲で変動した。術後は母豚の 興奮をさけるために, 測定を一時中断したが, 術後65分 より測定を再開した。術後65分値は $88 / \mathrm{min}$. を記録し たが，術後75分を経過した時点より上昇しはじめ，最高 148/min. にまで達した。

このような心拍数の变動は, 麻醉深度が比較的不安定 であったため，保定または切開による疼痛刺激の影響を 受けたものと考えられた。

体温の測定は, 保定操作ならびに手術操作の障害とな るため, また, 術後は母豚の興奮をさけるため, 術中お よび術後65分までは, 測定を中止した。術前の体温は $37.5^{\circ} \mathrm{C}$ で, 術後65分の体温は $37.6^{\circ} \mathrm{C}, 75$ 分後で $39.0^{\circ} \mathrm{C}$ と術前に比較して約 $1.5^{\circ} \mathrm{C}$ の上昇が観察された。

術後に打ける体温の上昇は，手術侵襲による影響と考 えられた。

呼吸数の測定は, 体温の測定と同じ理由で術中および 術後65分までは測定を中止した。術前および手術開始 15 分後までは, $20 \sim 30 / \mathrm{min}$. の変動であったが, 術後70分 より起立直前までの間は, $40 \sim 50 / \mathrm{min}$. の変動を示し た。

このような変動は体温の変動と関連し, 麻酷侵襲より も手術侵襲による影響とみられる所見であった。

\section{考察}

今回, われわれは, 塩酸ケタミンに GOF 麻醉を間歇 的併用し, 豚の帝王切開を実施したが, 術中の心拍数
は比較的高値を示した。この原因は麻醉深度が浅く，手 術操作による疼痛を十分に抑制することができなかった ためと考学られる。しかし，保定の操作に支障をきたさ ない程度の鎮静は十分に得られ，また，帝王切開に必要 な麻酔深度も十分であったと考兄られる。

また，手術開始 7 分を経過した頃に認められた心拍数 の一過性の急激な減少は, 開腹による腹圧の急激な低下 により生ずる血圧下降汇起因するものと推察された。

術後に打ける体温, 呼吸数ならびに心拍数が, 術前に 比較して高值を示している原因は，手術による疼痛括よ び炎症反応沉よるのと推察された。

摘出した胎児は, 全頭之も摘出直後より正常な呼吸様 式が観察され，心音も正常であった。摘出後 $3 \sim 5$ 分を 経過した頃より, 歩行しはじめ, 吸乳の動作が観察さ れ, 麻酔当初に䊝念された麻酔薬の影響は観察されなか った。

今回，われわれは，豚の帝王切開を行うに際して，硫 酸フトロピンによる Premedication を実施したのち, 主たる麻酔を塩酸ケタミンで行い， $2 \%$ 塩酸プロカイン による局所麻酔を併用しつつ,さらにハロセン, 笑気の 吸入による GOF 麻酔を補助的に実施した理由は, ペン トバルビタール酸剤や, 塩酸ケタミンなどの単味の投与 による麻醉方法では, 麻酔深度の調節が困難で, 母豚の 危険度が高いことならびに麻醉薬の胎児におよぼす影響 を考虑したものである。

八ロセン単味による吸入麻酔では, 血圧の低下が著し く，4\%ハロセンを 5 分間吸入させた例では，50\%以上 の血圧降下が観察されたといら本好ら $(1968)^{6)}$ の報告も あり, ハロセン単味の吸入麻酔は, 極めて危険であると 考えられた。また，八ロセンおよびサクシンルコリンク ロライドを用いた場合に，悪性高熱症が発生するという Berman ら (1970) ${ }^{1)}$, および竹内ら $(1978)^{9)}$ の報告もあ るので，われわれは塩酸ケタミンの投与量を鎮静が得ら れる程度の投与量にとどめ, 間歇的に GOF 麻醉を併用

し，必要に応じた最小限度の麻醉を実施した。

近年, アザペロンおよび塩酸メトミデートなどの NLA (Neuroleptanalgesia) 飞, 局所麻醉を併用して帝王切 開を実施する方法が，本好 $(1974)^{8)}$ とよって報告されて おり, 今後, 検討する価值があると考えられた。

\section{文献}

1) Berman, M.C., Harrison, G.G., Bull, A.B. and Kench, J.E.: Changes underlying halothane induced malignant hyperpyrexia in Landrace Pigs. Nature 255: 653, 1970.

2) 獣医麻酔研究会編 獣医麻醉ハンドブック，第 1 
版, 79-89, 学空社, 東京, 1970.

3) 黒沢亮助, 酒井保共編：家畜外科診療，第 5 版, 384-385，養賢堂, 東京, 1970 .

4) L.E. Mount and D.L. Ingram: Anaesthesia The Pig as a Laboratory Animal,79-90,London Academic, 1971.

5) M. Westhues R. Fritsh 共著, 宮川知典訳：動 物の麻酔, 第 2 巻 全身麻酔, 186-187, 学空社, 東京, 1967.

6）本好茂一，熊谷丑二，伊東信夫，臼井和哉，幡谷 正明：豚の吸入麻酔に関する研究, ether および fluothane の効果について, 日獣学誌, 30 (Suppl)
242, 1968.

7) 本好茂一, 臼井和哉, 幡谷正明: 豚の吸入麻酔に 関する研究, I . 前麻剤の臨床的検討, 獣医麻酔, 第 1 号, 8-13, 1970.

8）本好茂一：麻酔法の選択と実際，2.豚における 麻酔法の選択と実際, 獣医麻酔, 第 5 号, 69-75, 1974.

9）竹内啓, 小川博之：豚の吸入麻酔時に認められた 悪性高熱様症状, 獣医麻醉, 第 9 号, 65-67, 1978.

10) William. V. Lumb. and E. Wynn Jones: Veteri nary Anesthesia, 25, 186, 198, 298-299, 384385, Lea and Febiger, Philadelphia, 1973.

\section{三共の犬·猫用薬绪}

\section{(9)}

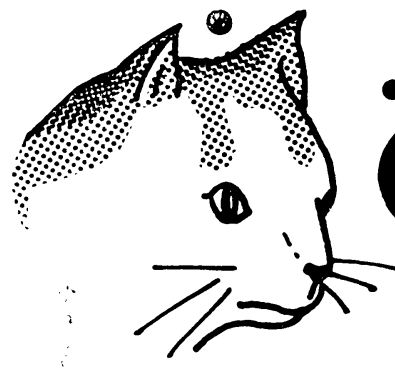

- 短時間全身麻酔剤

(非バルビタール系)

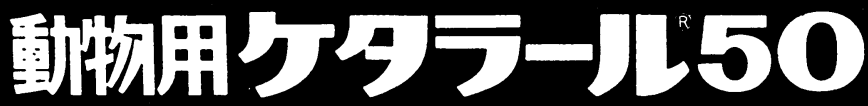

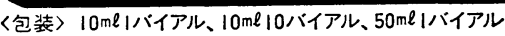

\section{〈特長〉}

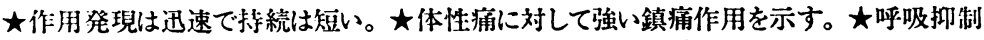

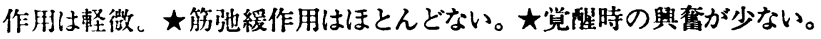

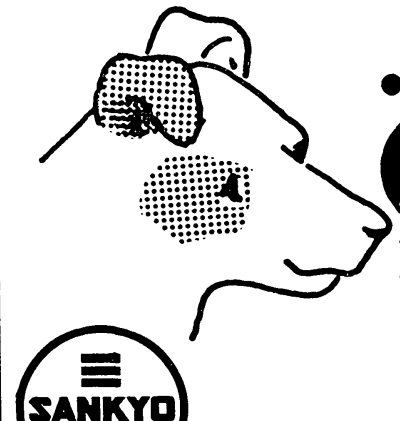

駆虫郕

（パーペンダソール製戍）

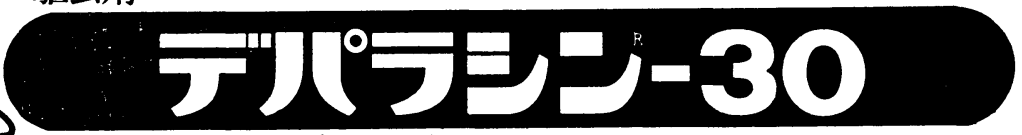

〈包装〉 $909(19 \times 3 \times 30) 、 1509(19 \times 3 \times 50)$

〈特長〉

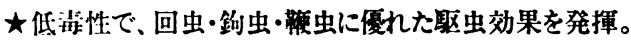

れ動物による忌避性がなく、飭やミルクに混ぜて容易に投与できる。 